Original scientific paper - Izvorni znanstveni rad

UDK: 637.112 .2

\title{
Somatic cell counts in raw ewes' milk in dairy practice: frequency of distribution and possible effect on milk yield and composition
}

doi: $10.15567 /$ mljekarstvo.2017.0402

\author{
Vladimír Tančin ${ }^{1,2 *}$, Štefan Baranovič², Michal Uhrinčat ${ }^{\prime 1}$, \\ Lucia Mačuhová ${ }^{1}$, Martina Vršková ${ }^{1}$, Marta Oravcová ${ }^{1}$ \\ ${ }^{1}$ National Agricultural and Food Centre, Research Institute for Animal Production Nitra, \\ Hlohovecká 2,951 41 Lužianky, Slovak Republic \\ ${ }^{2}$ Slovak University of Agriculture in Nitra, FAFR, Department of Veterinary Science, \\ Tr. A. Hlinku 2, 94901 Nitra, Slovak Republic
}

Received - Prispjelo: 06.06.2017. Accepted - Prihvaćeno: 27.09.2017.

\begin{abstract}
The aim of the work was to analyse the somatic cell counts (SCC) of the individual sheep milk samples under practical conditions. Totally 2159 samples were collected from four farms in April, May, June and July. Ewes were divided into five SCC groups on the basis of individual SCC: Low $=<200000$ cells. $\mathrm{mL}^{-1}$, Middle $=$ between 200000-400000 cells. $\mathrm{mL}^{1}$, Higher $=$ between $400000-$ 600000 cells.mL $\mathrm{mL}^{-1}$, High $=$ between 600000-1000000 cells.mL $\mathrm{mL}^{-1}$, Mastitis $=>1000000$ cells.mL ${ }^{-1}$ ). The percentage of distribution of individual milk samples in SCC groups was as followed: $71.79 \%$, $10.24 \%, 5.05 \%, 4.03 \%$ and $8.89 \%$ respectively. Thus $82.03 \%$ of samples of whole data set were below 400000 cells. $\mathrm{mL}^{-1}$ and only $8.89 \%$ over 1000000 cells.mL $\mathrm{mL}^{-1}$. Lacaune had a higher percentage of milk samples in the group Mastitis as compared to the other breeds or crossbreds. Factor SCC group reduced the milk yield, while a significant difference was observed in ewes of Mastitis SCC group as compared with ewes in Low SCC group ( $419 \pm 13 \mathrm{~mL}, 503 \pm 6 \mathrm{~mL}$, resp.). The high percentage of ewes in the first two SCC groups significantly contributes to the possible development of limits for sheep milk quality.
\end{abstract}

Key words: ewe's milk, somatic cell counts, milk yield, composition

\section{Introduction}

Breeding of sheep for multiple purposes (milk, wool and meat) has a long tradition in Slovakia. Therefore sheep breeding are currently the only livestock species whose number is stabilized in Slovakia (Gálik, 2016). At present more effort in sheep breeding is related to milk production. In Slovakia ewe's milk is mainly used for cheese making. Thus milk yield and milk quality is an important issue for sheep dairy practice. One of the mechanisms for improving the milk yield and milk composition is management of breeding. Important tools for good managements are keeping available information on individual production and health. However, in the past five years the number of animals included in milk recording decreased continuously (currently only about $14 \%$ of ewes) (Ryba and Dianová, 2016), despite the observed tendency to increase the milk yield due to crossing with Lacaune and better management of breeding systems.

Regular milk recording in Slovakia is mainly based on the analysis of milk composition, with exceptional analysis for somatic cell counts (SCC) (Margetín et al., 2013). SCC is widely considered as an indicator of udder health (Green et al., 2004). At the present, neither individual nor bulk samples of sheep's milk are usually analysed for SCC since the milk payment according to SCC is not implemented. Such regulations rely to the insufficiently clarified objective factors and relationships affecting 
the milk SCC in terms of physiological and pathological aspects (Fragkou et al., 2014), despite the fact that it is known that SCC is related to the presence of microorganisms in the mammary gland and thus udder health (McDougall et al., 2002; Suarez et al., 2002). Subclinical mastitis negatively influences cheese yield and its quality (Silanikove et al., 2014).

In Slovakia only few work was done to examine the individual SCC in practical conditions (Margetin et al., 1995; Margetín et al., 2013; Tančin et al., 2015; Vršková et al., 2015). One large study was done by Tomáška et al. (2015) who performed the bulk milk analysis of 1086 samples collected from the March to August and revealed that only $7.3 \%$ of samples were in category below 500000 cells $\mathrm{mL}^{-1}$; while $49 \%$ of bulk milk samples were above 1000000 cells $\mathrm{mL}^{-1}$. Thus a more detail research of the main factors contributing to high level of bulk SCC in dairy practice in Slovakia is required. One of the main approaches is to measure the SCC in individual milk samples of ewes.

The aim of the work was to measure the SCC and composition of the individual sheep milk samples under practical conditions, and to examine the importance of individual SCC on bulk SCC. Possible effect of SCC on milk yield and composition as well as effect of months and farm (breed of ewes) was studied.

\section{Material and methods}

The study was performed at four dairy farms with differed breeds and crossbreds under Slovakian usual practical conditions (milking and pasture). At the first and fourth farm purebred Tsigai (TS) ewes twere kept, at the second farm there were crossbred Improved Valachian x Lacaune ewes (IV/LC, - with higher proportion of Improved Valachian), at third farm there were kept two groups of ewes - 3a (crossbred ewes of synthetic population of Slovak dairy ewe - SD), and 3b (purebred Lacaune ewes - LC). At all farms the ewes were on pasture during the day and housed in stable during the night. Twice a day the machine milking in parlour was performed, whereat all animals received concentrates in amounts of 200 g per day . There were different dairy parlours in involved farms - first and third $1 \times 16$, second $1 \times 24$, fourth $2 \times 12$.
The milking of ewes started shortly before Easter (suckling lambs were sold) and lambing of the most ewes were within 3 weeks (January/February). The milk yield recording and milk sampling were performed once a month during evening milking as a part of milk recording services. Milk samples $(50 \mathrm{~mL})$ were collected from the whole milk yield into the recording jar (ICAR approved). Table 1 contains data on months of milk collection and numbers of animals involved at studied farms.

Table 1. Numbers of experimental ewes on farms in each month

\begin{tabular}{lccccc}
\hline \multirow{2}{*}{ Farm } & \multicolumn{5}{c}{ Month } \\
\cline { 2 - 6 } & April & May & June & July & Overall \\
\hline Farm 1 & & & 222 & 195 & 417 \\
\hline Farm 2 & & & 479 & 473 & 952 \\
\hline Farm 3a & 88 & 103 & 120 & 121 & 432 \\
\hline Farm 3b & 15 & 25 & 31 & 31 & 102 \\
\hline Farm 4 & 61 & 66 & 65 & 64 & 256 \\
\hline Overall & 164 & 194 & 917 & 884 & 2159 \\
\hline
\end{tabular}

The basic milk composition was determined by MilkoScan FT120 (Foss, Hillerød, Denmark) and somatic cells count were determined using a Fossomatic 90 (Foss Electric, Hillerød, Denmark) after heat treatment at $40{ }^{\circ} \mathrm{C}$ for $15 \mathrm{~min}$.

The percentage of milk samples distribution in different SCC groups was calculated within a farm and within a whole data set. The percentage of milk lost represented a volume of milk obtained from ewes with SCC over 1000000 cells $\mathrm{mL}^{-1}$ from whole milk obtained in bulk tank per milking.

Statistical analysis was performed by a SAS program (ver. 8.2; SAS Institute, 2001). The Somatic cells count was evaluated using logarithm values (log SCC). According to the individual SCC in milk of animals, the dairy ewes were divided into five SCC groups (SOMATIC) (Low = $<200000$ cells. $\mathrm{mL}^{-1}$, Middle $=$ between 200000400000 cells. $\mathrm{mL}^{-1}$, Higher $=$ between 400000600000 cells. $\mathrm{mL}^{-1}$, High $=$ between 6000001000000 cells. $\mathrm{mL}^{-1}$, Mastitis $=>1000000$ cells. $\mathrm{mL}^{-1}$ ). The effect of months (MONTH) was evaluated according to the months of milk sampling (April, May, June and July). Effect of the farm was studied taking into account the breeds why 5 groups (farm third divided into two because of two groups of breeds) were involved (first, second, third with SD ewes - 3a and third with LC ewes - 3b, fourth). Data are presented as LSM (Least Squares Means) \pm SE (Standard Error) per milking. 
The used statistical model (mixed model methodology) can be written as follows:

$\mathrm{y}_{i j n p}=\mu+$ SOMATIC $_{i}+$ MONTH $_{j}+$ FARM $_{n}+\mathrm{u}_{p}+\mathrm{e}_{i j n p}$

$\mathrm{y}_{\text {ijnp }}=$ the measurements for milk yield and composition (fat, protein, lactose and log SCC)

$\mu=$ overall mean,

SOMATIC $_{i}=$ the fixed effects of SCC groups ( $i=1$ to 5$)$,

$\mathrm{MONTH}_{j}=$ fixed effect of months of sampling ( $\mathrm{j}=1$ to 4$)$,

$\mathrm{FARM}_{n}=$ fixed effect of farms $(\mathrm{n}=1$ to 5$)$,

$\mathrm{u}_{p}=$ random effect of ewes, $\mathrm{u}_{p} \sim \mathrm{N}\left(0, \sigma_{u}^{2}\right)$,

$\mathrm{e}_{i j n p}=$ random error, assuming $\mathrm{e}_{i j n} \sim \mathrm{N}\left(0, \mathrm{I} \sigma_{e}^{2}\right)$.

The calculation of SCC in the bulk milk tank was evaluated by:

$\mathrm{SCC}_{T}$ - in bulk,

$$
S C C_{T}=\frac{\sum_{j=1}^{n} S C C_{j} * M Y_{j}}{\sum_{j=1}^{n} M Y_{j}}
$$

$\mathrm{SCC}_{1}, \mathrm{SCC}_{2}, \ldots \mathrm{SCC}_{j}$ - individual SCC at sampling day,

$\mathrm{MY}_{1}, \mathrm{MY}_{2}, \ldots \mathrm{MY}_{j}$ - individual milk yield per milking at sampling day

Table 2. Characteristics of statistical file of studied traits

\begin{tabular}{lccccc}
\hline Variable & $\mathrm{N}$ & Minimum & Maximum & LSM & SE \\
\hline Milk yield, $\mathrm{mL}$ & 2159 & 20 & 1400 & 384 & 4.47 \\
\hline SCC, $10^{3}$ cells.mL ${ }^{-1}$ & 2159 & 1 & 26741 & 509 & 41 \\
\hline $\log$ SCC & 2159 & 3.00 & 7.43 & 4.91 & 0.02 \\
\hline Fat, $\%$ & 2150 & 0.90 & 13.80 & 7.21 & 0.04 \\
\hline Proteins, $\%$ & 2150 & 3.96 & 11.06 & 5.90 & 0.02 \\
\hline Lactose, $\%$ & 2150 & 2.54 & 7.81 & 4.83 & 0.01 \\
\hline
\end{tabular}

LSM - least square means, SE - standard error

Table 3. Calculated somatic cells count $\left(10^{3}\right.$ cells $\left.\mathrm{mL}^{-1}\right)$ in bullk milk tank with and without the "Mastitis" group of ewes and the possible lost of milk (\%) in the "Mastitis" excluded from milk delivery

\begin{tabular}{|c|c|c|c|c|c|}
\hline \multirow{2}{*}{ Farms } & \multirow{2}{*}{ Month } & \multicolumn{3}{|c|}{ SCC in bulk milk tanks, $10^{3}$ cells.mL $\mathrm{mL}^{-1}$} & \multirow{2}{*}{$\begin{array}{l}\text { Lost Milk from } \\
\text { "Mastitis" ewes, } \%\end{array}$} \\
\hline & & with "Mastitis" ewes & without "Mastitis" ewes & Improvement, \% & \\
\hline \multirow{2}{*}{ Farm 1} & June & 289.63 & 140.52 & 51.48 & 7.71 \\
\hline & July & 150.07 & 92.11 & 38.62 & 1.92 \\
\hline \multirow{2}{*}{ Farm 2} & June & 248.42 & 124.51 & 49.88 & 5.98 \\
\hline & July & 126.24 & 63.75 & 49.50 & 3.79 \\
\hline \multirow{4}{*}{ Farm 3a } & April & 688.50 & 169.04 & 75.45 & 7.56 \\
\hline & May & 518.48 & 169.29 & 67.35 & 5.74 \\
\hline & June & 794.90 & 175.85 & 77.88 & 9.89 \\
\hline & July & 916.88 & 204.26 & 77.72 & 13.56 \\
\hline \multirow{4}{*}{ Farm 3b } & April & 1392.04 & 285.90 & 79.46 & 38.97 \\
\hline & May & 1056.77 & 160.98 & 84.77 & 24.43 \\
\hline & June & 483.18 & 184.00 & 61.92 & 16.74 \\
\hline & July & 1103.99 & 155.83 & 85.88 & 19.05 \\
\hline \multirow{4}{*}{ Farm 4} & April & 1292.22 & 304.41 & 76.44 & 15.47 \\
\hline & May & 740.24 & 232.68 & 68.57 & 15.80 \\
\hline & June & 843.62 & 251.97 & 70.13 & 16.33 \\
\hline & July & 670.02 & 199.62 & 70.21 & 12.03 \\
\hline All farms & Total & 484.21 & 146.34 & 69.78 & 8.73 \\
\hline
\end{tabular}




\section{Results and discussion}

Table 2 contains the basic statistics of the studied traits.

Table 3 presents SCC in the bulk milk tank calculated on the base of individual SCC and the individual yield, if such milk would be mixed together. For all samples mixed together, the SCC reached a level of $480000 \pm 140000$ cells $\mathrm{mL}^{-1}$ which is similar to average values in Table 2 . If we consider the data of individual farms and months, only at the first two farms the means of SCC were below 500000 cells $\mathrm{mL}^{-1}$ as it was generally found out by Tomáška et al. (2015). Therefore the third column in Table 3 represents the calculated SCC in the bulk milk tank without individual ewes whose SCC was over 1000000 cells $\mathrm{mL}^{-1}$ (SCC group Mastitis). Discharging the milk from the ewes of Mastitis SCC group, asignificant reduction in SCC of the bulk milk tank was achieved, though there was a different effect on the reduction milk amount delivered to dairy or processed in farm as calculated from the actual milk yield in tank per milking (Table 3). It could be noted that reducing the number of animals with SCC over 1000000 cells $\mathrm{mL}^{-1}$ could be an effective way for reduce the SCC in the bulk milk tank. There was a high probability that high SCC (over 1000000 cells $\mathrm{mL}^{-1}$ or even more) was related to the presence of udder infection with minor or major pathogens (Suarez et al., 2002). Riggio et al. (2013) found that from the culture negative samples, $83.7 \%$ had SCC $<500000$ cells $\mathrm{mL}^{-1}$ and $97.4 \%$ had $<1000000$ cells $\mathrm{mL}^{-1}$.

The results in Table 3 lead to a question related to the distribution of animals in different SCC groups especially of animals in the group over 1000000 cells $\mathrm{mL}^{-1}$. On the basis of individual analysis of milk samples for SCC it was possible to distribute animals into five different SCC groups (Table 4). Out of the 2159 samples collected in total, 1550, 221, 109, 87 and 192 were divided in low, middle, higher, high and mastitis SCC groups respectively and thus it represents a percentage as followed: $71.79 \%, 10.24 \%$, $5.05 \%, 4.03 \%$ and $8.89 \%$ respectively. According to data in Table 4, most of the animals had SCC in milk below 400000 cells $\mathrm{mL}^{-1}$ (82.03\%). Which might be the most important finding of the presents research.The percentage was influenced by farms, season, purebreed or crossbreed origin. At the first two farms the percentage of ewes with SCC over
1000000 cells $\mathrm{mL}^{-1}$ was very low (Table 4) and the improvement of SCC in bulk milk tank without being milked was almost $50 \%$ (Table 3), though loss of the discharged milk reduced slightly. The high percentage of ewes in Mastitis group at other farms and months (Table 4) increased the loss of the discharged milk dramatically (Table 3), if milk of ewes from Mastitis group would not be included.

Under the same management conditions at farm 3 there was possible to see the effect of breed (Table 4). LC had higher percentage of samples over 1000000 cells $\mathrm{mL}^{-1}$ as compared to SD and the highest if compared to other breeds/farms. The effect of farm management (farm 1 and 4) with the same breed (TS) was also an important factor (Table 4) contributing to the SCC in individual ewes. More detail study of differences in farm management at mentioned farms would be required, but it was not within the scope of our study.

The distribution of milk samples into different SCC groups revealed that more emphasis should be concentrated to the work with ewes showing over 1000000 cells $\mathrm{mL}^{-1}$. Low percentage of animals with SCC over 1000000 cells $\mathrm{mL}^{-1}$ (whole dataset) could indicate subclinical health problems of the udder rather than physiological factors taking into account in small ruminants. Recently Kuchtik et al. (2017) reported very low level of SCC in milk of Lacaune ewes throughout lactation (range 36000-480000 cells $\mathrm{mL}^{-1}$ ) too. Berthelot et al. (2006) reported healthy ewes with SCC below 500000 cells $\mathrm{mL}^{-1}$ and infected udders with SCC higher than 1000000 cells $\mathrm{mL}^{-1}$. The literature reports a reduced individual SCC in ewes during past few years (Pengov, 2001; Berthelot et al., 2006; Arias et al., 2012). Riggio et al. (2013) stated that in uninfected Valle del Belice ewes, $83.7 \%$ of the samples were in the category below 500000 cells $\mathrm{mL}^{-1}$ and only $2.6 \%$ above 1000000 cells $\mathrm{mL}^{-1}$. According to Prpić et al. (2016), in healthy 80 East Friesian ewes the SCC was low (log SCC \pm SE for ewes with singles and twins $5.11 \pm 0.03$ and $4.95 \pm 003$ respectively) but in infected ewes the SCC significantly increased $(5.85 \pm 0.06 \quad 6.22 \pm 0.06$ respectively). Though very low percentage of animals in Mastitis group was detected at some farms, one farm at which $40 \%$ of animals were detected in Mastitis group also occurred. On farm level, the subclinical mastitis was detected at 15 to $40 \%$ of the ewes (Kiossis et al., 2007; Contreras et al., 2007). 
It is possible to point out that despite the effect related to months of year, farms or breeds (Table 4), most of the raw milk samples were in the first two or three SCC groups, why udder health appeared to be the most important factor affecting SCC. According to Suarez et al. (2002), Riggio et al. (2013) and Skapetas et al. (2017), as well as data of the present study, the individual SCC in raw milk of ewes could not be classified as a problem, if good management and effective mastitis control program were performed at sheep farms. This supports findings of Paape et al. (2007) who reported SCC in milk of ewes being similar to dairy cows.
Factor SCC group reduced milk yield but significant difference was observed in ewes of Mastitis SCC group in comparison to ewes in the Low SCC group (419 $\pm 13 \mathrm{~mL}, 503 \pm 6 \mathrm{~mL}$, resp.). Negative phenotypic correlation between SCC and milk production in different breeds was reported by several authors in Manchega ewes (Arias et al., 2012) and in Churra ewes (Gonzalo et al., 2002). Špánik et al. (1996) calculated the negative correlation between SCC and the milk yield. A significantly negative correlation between SCC and milk production in Tsigai ewes during both, suckling and milking period was also found by Margetin et al.

Table 4. Frequency of distribution (\%) of milk ewes according to SCC groups in farms per months and per whole data set for all farms

\begin{tabular}{|c|c|c|c|c|c|c|}
\hline \multirow{2}{*}{ Farm - Breed } & \multirow[b]{2}{*}{ Month } & \multicolumn{5}{|c|}{ SCC group } \\
\hline & & Low & Middle & Higher & High & Mastitis \\
\hline \multirow{2}{*}{ Farm 1 - TS } & June & 69.37 & 9.46 & 6.31 & 4.50 & 10.36 \\
\hline & July & 84.62 & 3.59 & 5.64 & 4.10 & 2.05 \\
\hline \multirow{2}{*}{ Farm 2 - IV/LC } & June & 77.04 & 8.98 & 3.76 & 3.97 & 6.26 \\
\hline & July & 87.74 & 3.81 & 2.54 & 2.11 & 3.81 \\
\hline \multirow{4}{*}{ Farm 3a - SD } & April & 69.32 & 10.23 & 5.68 & 3.41 & 11.36 \\
\hline & May & 67.96 & 12.62 & 4.85 & 5.83 & 8.74 \\
\hline & June & 67.50 & 14.17 & 3.33 & 5.00 & 10.00 \\
\hline & July & 58.67 & 14.88 & 5.79 & 5.79 & 14.87 \\
\hline \multirow{4}{*}{ Farm 3b - LC } & April & 26.67 & 26.67 & 0.00 & 6.67 & 40.00 \\
\hline & May & 52.00 & 8.00 & 12.00 & 0.00 & 28.00 \\
\hline & June & 61.29 & 9.68 & 3.23 & 9.68 & 16.13 \\
\hline & July & 51.61 & 25.81 & 0.00 & 0.00 & 22.58 \\
\hline \multirow{4}{*}{ Farm 4 - TS } & April & 29.51 & 29.51 & 13.11 & 9.84 & 18.03 \\
\hline & May & 48.48 & 19.70 & 13.64 & 3.03 & 15.15 \\
\hline & June & 38.46 & 26.15 & 10.77 & 4.62 & 20.00 \\
\hline & July & 57.81 & 15.63 & 7.81 & 4.69 & 14.06 \\
\hline All farms* & & 71.79 & 10.24 & 5.05 & 4.03 & 8.89 \\
\hline
\end{tabular}

*Percentage of samples distribution for all farms was calculatd as real number of samples in different SCC groups (sum of all farms and months) divided by whole number of samples* 100 .

Low $=$ SCC $<0.2 \times 10^{6}$ cells. $\mathrm{mL}^{-1}$, Middle $=$ SCC between $0.2-0.4 \times 10^{6}$ cells. $\mathrm{mL}^{-1}$

Higher = SCC between 0.4-0.6 × $10^{6}$ cells. $\mathrm{mL}^{-1}$

High = SCC between 0.6-1 $\times 10^{6}$ cells. $\mathrm{mL}^{-1}$, Mastitis $=\mathrm{SCC}>1 \times 10^{6}$ cells. $\mathrm{mL}^{-1}$

TS - Tsigai, IV - Improved Valachian, LC - Lacaune, SD - Slovak dairy ewe

Table 5. The effect of SCC groups on milk yield and milk composition

\begin{tabular}{|c|c|c|c|c|c|c|c|c|c|c|c|}
\hline \multirow[b]{3}{*}{ Variable } & \multicolumn{10}{|c|}{ SCC groups } & \multirow[b]{3}{*}{$\mathrm{P}$} \\
\hline & \multicolumn{2}{|c|}{ Low } & \multicolumn{2}{|c|}{ Middle } & \multicolumn{2}{|c|}{ Higher } & \multicolumn{2}{|c|}{ High } & \multicolumn{2}{|c|}{ Mastitis } & \\
\hline & LSM & SE & LSM & SE & LSM & SE & LSM & SE & LSM & SE & \\
\hline Milk yield, $\mathrm{mL}$ & $503^{a}$ & 6.61 & $450^{\mathrm{bc}}$ & 12.33 & $455^{\mathrm{bc}}$ & 17.43 & $465^{\mathrm{ab}}$ & 19.45 & $419^{c}$ & 13.22 & $<0.0001$ \\
\hline Fat, $\%$ & $6.32^{\mathrm{a}}$ & 0.058 & $6.29^{\mathrm{a}}$ & 0.093 & $5.95^{\mathrm{b}}$ & 0.123 & $6.18^{\mathrm{ab}}$ & 0.137 & $6.23^{\mathrm{a}}$ & 0.099 & 0.0298 \\
\hline Protein, \% & $5.6^{\mathrm{a}}$ & 0.028 & $5.61^{\mathrm{a}}$ & 0.045 & $5.44^{\mathrm{b}}$ & 0.06 & $5.56^{\mathrm{ab}}$ & 0.066 & $5.68^{\mathrm{a}}$ & 0.048 & 0.0117 \\
\hline Lactose, $\%$ & $4.88^{\mathrm{a}}$ & 0.015 & $4.84^{\mathrm{ab}}$ & 0.024 & $4.76^{c}$ & 0.032 & $4.78^{\mathrm{bc}}$ & 0.036 & $4.58^{\mathrm{d}}$ & 0.026 & $<0.0001$ \\
\hline
\end{tabular}

${ }^{\mathrm{a}-\mathrm{d}}$ within row significantly different at $\mathrm{P}<0.05$

see Table 4. 
(1996). Though significant effect of SCC groups on fat and protein content (Table 5) was found in this study, the effect was not related to the increasing SCC groups as recently presented for higher protein and fat content in a group of ewes with high SCC (Vršková et al., 2015) or presented by de Olives et al. (2013). There was a negative effect of SCC on the lactose content (Table 5) which corresponded well to numerous previous studies (Bianchi et al., 2004; Olechnowicz et al., 2009; Mioč et al., 2009, Olives et al., 2013).

A significant effect of farm on milk yield, composition and log SCC could be obsereved, especially if the first farm was compared to the fourth farm where the same breed was raised (Table 6). Also the effect of the breed at the same farm (farm 3) could indicate that the risk for udder health problem increased along with increasing the milk production. Higher SCC was found in LC in comparison to the Manchega ewes (Rovai et al., 2014).

The months of milk sampling significantly influenced the observed traits (Table 7) as it was recently published by Skapetas et al. (2017). Because of the short lambing period, the months of milk sampling could be considered as an effect of advance stage of lactation. The milk yield, protein and fat content had similar progress as recently published for TS and IV breeds (Oravcová et al., 2015). According to Gonzalo et al. (1994), log SCC, fat and protein percentages increased along the lactation period by $31.2,37.6$, and $20.3 \%$ respectively, which was not obsereved for log SCC in this study. Even in July the log SCC dramatically decreased. Similar reduction of SCC during lactation of crossbred ewes was published by Mioč et al. (2009).

\section{Conclusion}

According to the obtained results $82.03 \%$ of the tested samples were below 400.000 cells $\mathrm{mL}^{-1}$ and only $8.89 \%$ over 1000000 cells.mL $\mathrm{m}^{-1}$ indicating a good status of udder health in tested animals. Lacaune had higher percentage of milk samples in group over 1000000 cells $\mathrm{mL}^{-1}$ as compared to other breeds or crossbreds. High percentage of ewes' milk samples in the first two SCC groups may contribute to the development of legislative limits for sheep milk quality as it is accepted for dairy cows.

Table 6. Milk yield, somatic cells count and milk composition in farms (breeds or crossbreds)

\begin{tabular}{|c|c|c|c|c|c|c|c|c|c|c|c|}
\hline \multirow[b]{3}{*}{ Variable } & \multicolumn{10}{|c|}{ Farms } & \multirow[b]{3}{*}{$\mathrm{P}$} \\
\hline & \multicolumn{2}{|c|}{ First (TS) } & \multicolumn{2}{|c|}{ Second (IV/LC) } & \multicolumn{2}{|c|}{ Third (SD) } & \multicolumn{2}{|c|}{ Third (LC) } & \multicolumn{2}{|c|}{ Fourth (TS) } & \\
\hline & LSM & SE & LSM & SE & LSM & SE & LSM & SE & LSM & SE & \\
\hline Milk yield, $\mathrm{mL}$ & $373^{a}$ & 13.6 & $384^{a}$ & 9.94 & $509^{b}$ & 9.21 & $655^{c}$ & 18 & $371^{\mathrm{a}}$ & 10.93 & $<0.0001$ \\
\hline $\log$ SCC & $4.45^{\mathrm{a}}$ & 0.056 & $4.55^{\mathrm{b}}$ & 0.041 & $5.23^{c}$ & 0.039 & $5.47^{\mathrm{d}}$ & 0.071 & $5.39^{d}$ & 0.052 & $<0.0001$ \\
\hline Fat, \% & $5.92^{\mathrm{a}}$ & 0.105 & $6.55^{\mathrm{b}}$ & 0.081 & $5.86^{\mathrm{a}}$ & 0.074 & $5.54^{\mathrm{c}}$ & 0.123 & $7.11^{\mathrm{d}}$ & 0.091 & $<0.0001$ \\
\hline Protein, $\%$ & $5.73^{\mathrm{a}}$ & 0.051 & $5.86^{\mathrm{b}}$ & 0.039 & $5.13^{c}$ & 0.036 & $5.1^{c}$ & 0.059 & $6.09^{\mathrm{d}}$ & 0.044 & $<0.0001$ \\
\hline Lactose, $\%$ & $4.94^{\mathrm{a}}$ & 0.027 & $4.97^{\mathrm{a}}$ & 0.021 & $4.64^{\mathrm{b}}$ & 0.019 & $4.59^{b}$ & 0.032 & $4.69^{c}$ & 0.024 & $<0.0001$ \\
\hline
\end{tabular}

a-d within row significantly different at $\mathrm{P}<0.05$

Table 7. Influence of months on milk yield, SCC and milk composition

\begin{tabular}{|c|c|c|c|c|c|c|c|c|c|}
\hline \multirow[b]{3}{*}{ Variable } & \multicolumn{8}{|c|}{ Month } & \multirow[b]{3}{*}{$\mathrm{P}$} \\
\hline & \multicolumn{2}{|c|}{ April } & \multicolumn{2}{|c|}{ May } & \multicolumn{2}{|c|}{ June } & \multicolumn{2}{|c|}{ July } & \\
\hline & LSM & SE & LSM & SE & LSM & SE & LSM & SE & \\
\hline Milk yield, mL & $532^{\mathrm{a}}$ & 14.77 & $552^{\mathrm{a}}$ & 13.68 & $441^{\mathrm{b}}$ & 8.69 & $309^{c}$ & 8.55 & $<0.0001$ \\
\hline $\log$ SCC & $5.12^{\mathrm{ab}}$ & 0.059 & $5.02^{\mathrm{a}}$ & 0.053 & $5.21^{\mathrm{b}}$ & 0.041 & $4.72^{\mathrm{c}}$ & 0.043 & $<0.0001$ \\
\hline Fat, \% & $5.89^{\mathrm{a}}$ & 0.104 & $5.68^{\mathrm{a}}$ & 0.096 & $5.78^{\mathrm{a}}$ & 0.077 & $7.42^{\mathrm{b}}$ & 0.082 & $<0.0001$ \\
\hline Protein, \% & $5.37^{\mathrm{a}}$ & 0.051 & $5.64^{\mathrm{b}}$ & 0.046 & $5.48^{c}$ & 0.037 & $5.82^{\mathrm{d}}$ & 0.04 & $<0.0001$ \\
\hline Lactose, \% & $4.87^{\mathrm{a}}$ & 0.027 & $4.74^{\mathrm{b}}$ & 0.025 & $4.84^{\mathrm{a}}$ & 0.02 & $4.62^{c}$ & 0.021 & $<0.0001$ \\
\hline
\end{tabular}

${ }^{\text {a-d }}$ within row significantly different at $\mathrm{P}<0.05$ 


\section{Acknowledgement}

This study was funded by the APVV-15-0072 (90\%) and Kega 006SPU-4/2014 (10\%) projects.

\section{Broj somatskih stanica u sirovom ovčjem mlijeku u mljekarskoj praksi: učestalost distribucije i mogući učinak na količinu i sastav mlijeka}

\section{Sažetak}

Cilj rada bio je analizirati broj somatskih stanica (SCC) individualnih uzoraka ovčjeg mlijeka ovaca na farmama. Prikupljeno je ukupno 2159 uzoraka s četiri farme tijekom travnja, svibnja, lipnja i srpnja. Ovce su bile podijeljene $\mathrm{u}$ pet SCC skupina na temelju pojedinačnih SCC vrijednosti: niska $=<200.000$ stanica. $\mathrm{mL}^{-1}$, srednja $=$ između 200.000-400.000 stanica. $\mathrm{mL}^{-1}$, viša $=$ između $400.000-600.000$ stanica. $\mathrm{mL}^{-1}$, visoka $=600.000-1.000 .000$ stanica. $\mathrm{mL}^{-1}$, mastitis $=>1.000 .000$ stanica. $\mathrm{mL}^{-1}$ ). Postotak distribucije pojedinačnih uzoraka mlijeka u SCC skupinama bio je kako slijedi: 71,79 \%, 10,24 \%, 5,05 \%, 4,03 \% i $8,89 \%$. Tako je $82,03 \%$ svih ispitivanih uzoraka sadržavalo manje od 400.000 stanica $\mathrm{mL}^{-1}$, a samo je 8,89 \% sadržavalo više od 1.000 .000 stanica $\mathrm{mL}^{-1}$. Pasmina Lacaune imala je veći postotak uzoraka mlijeka u skupini "Mastitis" u usporedbi s ostalim pasminama ili križancima. Faktor SCC utjecao je na smanjenje prinosa mlijeka u skupini, dok je značajna razlika zabilježena kod ovaca svrstanih u "Mastitis SCC" skupinu $\left(419 \pm 13 \mathrm{~mL}^{-1}\right)$ u usporedbi s ovcama $\mathrm{u}$ "Niska SCC" skupini (503 $\pm 6 \mathrm{~mL})$. Visok postotak ovaca u prve dvije "SCC skupine" značajno pridonosi mogućem razvoju graničnih vrijednosti broja somatskih stanica za definiranje kvalitete ovčjeg mlijeka.

Ključne riječi: ovčje mlijeko, broj somatskih stanica, količina mlijeka, sastav

\section{References}

1. Arias, R., Oliete, B., Ramon, M., Arias, C., Gallego, R., Montoro, V., Gonzalo, C., Perez-Guzman, M.D. (2012): Long-term study of environmental effects on test-day somatic cell count and milk yield in Manchega sheep. Small Ruminant Research 106 (2-3), 92-97. https://doi.org/10.1016/j.smallrumres.2012.03.019

2. Berthelot, X., Lagriffoul, G., Concordet, D., Barilett, F., Bergonier, D. (2006): Physiological and pathological thresholds of somatic cell counts in ewe milk. Small Ruminant Research 62 (1-2), 27-31. https://doi.org/10.1016/j.smallrumres.2005.07.047

3. Bianchi, L., Bolla, A., Budelli, E., Caroli, A., Casoli, C., Pauselli, M., Duranti, E. (2004): Effect of udder health status and lactation phase on the characteristics of Sardinian ewe milk. Journal of Dairy Science 87 (8), 2401-2408. https://doi.org/10.3168/jds.S0022-0302(04)73362-7

4. Contreras, A., Sierra, D., Sanchez, A., Corrales, J.C., Marco, J.C., Paape, M.J., Gonzalo, C. (2007): Mastitis in small ruminants. Small Ruminant Research 68 (1), 145-153. https://doi.org/10.1016/j.smallrumres.2006.09.011

5. Fragkou, I.A., Boscos, C.M., Fthenakis, G.C. (2014): Diagnosis of clinical or subclinical mastitis in ewes. Small Ruminant Research 118 (1-3), 86-92. https://doi.org/10.1016/j.smallrumres.2013.12.015

6. Gálik, J. (2016): Sheep. Situation and Outlook Report 31.12. 2015, NPPC-VÚEPP : Bratislava. 24 (1), 5-6.

7. Gonzalo, C., Carriedo, J.A., Baro, J.B., Primitivo, F.S. (1994): Factors influencing variation of test day milk yield, somatic cell count, fat, and protein in dairy sheep. Journal of Dairy Science 77 (6), 1537-1542. https://doi.org/10.3168/jds.S0022-0302(94)77094-6

8. Gonzalo, C., Ariznabarreta, A., Carriedo, J.A., San Primitivo, F. (2002): Mammary pathogens and their relationship to somatic cell count and milk yield losses in dairy ewes. Journal of Dairy Science 85 (6), 1460-1467. https://doi.org/10.3168/jds.S0022-0302(02)74214-8

9. Green, M.J., Green, L.E., Schukken, Y.H., Bradley, A.J., Peeler, E.J., Barkema, H.W., Medley, G.F. (2004): Somatic cell count distributions during lactation predict clinical mastitis. Journal of Dairy Science 87 (5), 1256-1264. https://doi.org/10.3168/jds.S0022-0302(04)73276-2

10. Kiossis, E., Brozos, C.N., Petridou E., Boscos, C. (2007): Program for the control of subclinical mastitis in dairy Chios breed ewes during lactation. Small Ruminant Research 73 (1-3), 194-199. https://doi.org/10.1016/j.smallrumres.2007.01.021

11. Kuchtík, J., Konečná, L., Sýkora, V., Šustová, K., Fajman, M., Kos, I. (2017): Changes of physicochemical characteristics, somatic cell count and curd quality during lactation and their relationships in Lacaune ewes. Mljekarstvo 67 (2), 138-145. https://doi.org/10.15567/mljekarstvo.2017.0206

12. Margetin, M., Čapistrák, A., Valkovsky, P., Špánik, J., Foltys, V. (1995): Variation in somatic-cell counts in ewes milk during lactation. Živočíšna výroba 40 (6), 257-261. 
13. Margetin, M., Čapistrák, A., Špánik, J., Foltys, V. (1996): Somatic cells in sheep milk in relation to milk production and composition during sucking and milking. Živočišna výroba 41 (12), 543-550.

14. Margetín, M., Milerski, M., Apolen, D., Čapisták, A., Oravcová, M., Debrecéni, O. (2013): Relationships between production, quality of milk and udder health status of ewes during machine milking. Journal of Central European Agriculture 14 (1), 328-340. https://doi.org/10.5513/JCEA01/14.1.1203

15. McDougall, S., Pankey, W., Delaney, C., Barlow, J., Murdough, PA., Scruton, D. (2002): Prevalence and incidence of subclinical mastitis in goat and dairy ewes in Vermont, USA. Small Ruminant Research 46 (2-3), 115-121. https://doi.org/10.1016/S0921-4488(02)00191-8

16. Mioč, B., Prpić, Z., Antunac, N., Antunović, Z., Samaržija, D., Vnučec, I., Pavić, V. (2009): Milk yield and quality of Cres sheep and their crosses with Awassi and East Friesian sheep. Mljekarstvo 59 (3), 217-224.

17. Olechnowicz, J., Jaśkowski, J.M., Antosik, P., Bukowska, D. (2009): Milk yield and composition in line 05 dairy ewes as related to somatic cell counts. Journal of Animal and Feed Science 18 (3), 20-428. https://doi.org/10.22358/jafs/66417/2009

18. Olives de, A.M., Díaz, J.R., Molina, M.P., Peris, C. (2013): Quantification of milk yield and composition changes as affected by subclinical mastitis during the current lactation in sheep. Journal of Dairy Science 96 (12), 7698-7708. https://doi.org/10.3168/jds.2013-6998

19. Oravcová, M., Margetín, M., Tančin, V. (2015): The effect of stage of lactation on daily milk yield, and milk fat and protein content in Tsigai and Improved Valachian ewes. Mljekarstvo 65 (1), 48-56. https://doi.org/10.15567/mljekarstvo.2015.0107

20. Paape, M.J., Wiggans, G.R., Bannermana, D.D., Thomasc, D.L., Sanders, A.H., Contreras, A., Moroni, P., Mastitiser, R.H. (2007): Monitoring goat and sheep milk somatic cell counts. Small Ruminant Research 68 (1), 114-125. https://doi.org/10.1016/j.smallrumres.2006.09.014

21. Pengov, A. (2001): The role of coagulase-negative Stahylococcus spp. and associated somatic cell count in the ovine mammary gland.Journal of Dairy Science 84 (3), 572-574. https://doi.org/10.3168/jds.S0022-0302(01)74509-2

22. Prpić, Z., Vnučec, I., Benić, M., Mioč, B. (2016): Relationship of litter size with milk yield, udder morphology and udder health of East Friesian sheep. Journal of Central European Agriculture 17 (4), 1331-1345. https://doi.org/10.5513/JCEA01/17.4.1853

23. Riggio, V., Pesce, L.L., Morreale, S., Portolano, B. (2013): Receiver-operating characteristic curves for somatic cell scores and california mastitis test in Valle del Belice dairy sheep. The Veterinary Journal 196 (3), 528-532. https://doi.org/10.1016/j.tvj1.2012.11.010
24. Rovai, M., Caja, G., Salama, A.A.K., Jubert, A., Lázaro, B., Lázaro, M., Leitner, G. (2014): Identifying the major bacteria causing intramammary infections in individual milk samples of sheep and goats using traditional bacteria culturing and real-time polymerase chain reaction. Journal of Dairy Science 97 (9), 5393-5400. https://doi.org/10.3168/jds.2014-7988

25. Ryba, Š., Dianová, M. Výsledky kontroly úžitkovosti oviec za kontrolný rok 2013/2014 [The results of performance of sheep in the control year 2013/2014] [online], [cit. 2016-10-25].

URL: <http://www.agroporadenstvo.sk/index.php?start $\& \mathrm{t}=$ zivocisna-vyroba-ovce\& $\mathrm{t} 2=\&$ article $=641>$.

26. Silanikove, N., Merin, U., Leitner, G. (2014): On effects of subclinical mastitis and stage of lactation on milk quality in goats. Small Ruminant Research 122 (1-3), 76-82. https://doi.org/10.1016/j.smallrumres.2014.07.018

27. Skapetas, B., Bampidis, V., Christodoulou, V., Kalaitzidou, M. (2017): Fatty acid profile, somatic cell count and microbiological quality of total machine milk and hand stripped milk of Chios ewes. Mljekarstvo 67 (2), 146-154. https://doi.org/10.15567/mljekarstvo.2017.0207

28. Suarez, V.H., Busetti, M.R., Miranda, A.O., Calvinho, L.F., Bedotti, D.O., Canavesio, V.R. (2002): Effect of infectious status and parity on somatic cell count and California mastitis test in pampinta dairy ewes. Journal of Veterinary Medicine 49 (5), 230-234. https://doi.org/10.1046/j.1439-0450.2002.00552.x

29. SAS Institute. 2001. Version 8.2. SAS Institute Inc., Cary, NC.

30. Špánik, J., Kačincová, A., Margetín, M., Čapistrák, A., Kališ, M. (1996): Dependence of sheep milk quality on somatic cell counts. Journal Farm of Animal Science 29 (1), 111-116.

31. Tančin, V., Uhrinčat, M., Baranovič, Š., Mačuhová, L., Sláma, P. (2015): Relationships between production, quality of milk and udder health status of ewes during machine milking. Food Hygiene and Technology $-45^{\text {th }}$ Lenfeld's and Hökl's Days, 14-15 Oktober, University of Veterinary and Pharmaceutical Sciences, Brno. 193197.

32. Tomáška, M., Hofericová, M., Klimešová, M., Hanuš, O., Vorlová, L., Kološta, M. (2015): Occurrence of somatic cells in bulk samples of raw sheep's milk. Food Hygiene and Technology. - 45 th Lenfeld's and Hökl's Days, 14-15 Oktober, University of Veterinary and Pharmaceutical Sciences Brno. 197-200.

33. Vršková, M., Tančin, V., Kirchnerová, K., Sláma, P. (2015): Impact of selected parameters on milk production in Tsigai breed. Journal of Microbiology, Biotechnology and Food Sciences 4 (3), 185-187. https://doi.org/10.15414/jmbfs.2015.4.special3.185-187 